\title{
On the issue of standardization of dry extract "Glyzyrrhiza 7"
}

\author{
(C) Tatiana V. Kornopoltseva, ${ }^{1 *^{+}}$and Elena A. Botoeva ${ }^{2}$ \\ ${ }^{1}$ Laboratory of Biomedical Research. Institute of General and Experimental Biology. \\ Sakhyanovoy St., 6. Ulan-Ude. Russia.Phone:+7 (9021)64-55-81.E-mail: tv-kornopol@mail.ru \\ ${ }^{2}$ Department of Obstetrics and Gynecology with the Course of Pediatrics. Buryat State University. \\ Smolin St., 24a. Ulan-Ude. Russia.
}

Keywords: adaptogens, biologically active substances.

*Supervising author; ${ }^{+}$Corresponding author

\begin{abstract}
A promising direction for the search and development of new adaptogenic drugs of natural origin is the study of nonspecific drugs from the arsenal of Tibetan medicine, recommended for the weakened, as well as for elderly people, as a general tonic, "giving longevity and health." Based on the prescription recipe "Glyzyrhiza-7", in the indications for use: "with pain in the kidneys, lower back, limb stiffness, sudden flushes of heat in different parts of the body" developed a dry plant extract from the roots Glyzyrrhiza uralensis Fisch, wood Caragana jubata (Pall.) Poir, roots Polygonatum odoratum (Mill) Druse, roots Polygonatum humile Fisch ex Maxim, bulbs Orchis mascula L., roots Rheum rhabarbarum L., roots Rubia tinctorum L. HPLC in the dry extract revealed the presence of ten marker components whose raw material source is Rheum (deoxyraponticin, raponticin, rapontigenin, caffeic acid), Glyzyrrhiza (likuritin, glycyrrhizinic acid), Rubia (alizarin, purpurine, ruberitrinic acid, lucidin-primverozid) The dominant compounds of the licorice 7 extract are anthraquinones, the content of which was $7.65 \mathrm{mg} / \mathrm{g}$; stelben content $6.13 \mathrm{mg} / \mathrm{g}$; terpenes (glycyrrhizic acid) $1.67 \mathrm{mg} / \mathrm{g}$, flavonoids and phenol carboxylic acids account for 2.07 and $1.12 \mathrm{mg} / \mathrm{g}$, respectively. A technique has been developed for the quantitative determination of the content of glycyrrhizic acid in the dry extract $(16.5 \%)$, which can be used to standardize this object.
\end{abstract}

\section{References}

[1] USSR State Pharmacopoeia. XI ed. Moscow. 1990. Part 2. P.364-365. (russian)

[2] M.V. Egorov, V.A. Kurkin, G.G. Zapesochnaya, V.A. Bykov. Validation of methods for qualitative analysis of raw materials and licorice preparations. Pharmacy. 2005. Vol.53. No.1. P.9-12. (russian)

[3] M.V. Egorov, V.A. Kurkin. Improving methods of licorice root standardization. Izvestia Samara Scientific Center of the Russian Academy of Sciences. 2011. Vol.13. No.1(8). P.1992-1995. (russian)

[4] Plant resources of Russia: Wild flowering plants, their component composition and biological activity. In 6 t. T.1. Families Magnoliaceae-Julandaceae, Ulmaceae, Moraceae, Cannabaceae, Urticaceae. status Belenovskaya L.M., Lesiovskaya E.E., Bobyleva N.S. St.Petersburg: M. 2008. 421p. (russian)

[5] Plant Resources of Russia: Wild flowering plants, their component composition and biological activity. In 6 t. T.3. Fabaceae-Apiaceae families. status L.M. Belenovskaya, E.E. Lesiovskaya, N.S. Bobylev. St.Petersburg: M. 2010. 601p. (russian)

[6] Plant resources of Russia: Wild flowering plants, their component composition and biological activity. In 6 t. Vol.4. Families of Caprifoliaceae-Lobeliaceae. status L.M. Belenovskaya, E.E. Lesiovskaya, N.S. Bobylev. St.Petersburg: M. 2011. 513p. (russian)

[7] Plant Resources of Russia: Wild flowering plants, their component composition and biological activity. In 6 t. T.6. Family Butomaceae-Typhaceae). status Belenovskaya L.M., Lesiovskaya E.E., Bobyleva N.S. St.Petersburg: M. 2014. 391p. (russian)

[8] Sumati Prajna. Kunpan-Dudzi (Amrita Extract, useful for all). A great recipe directory Agin datsan. Sumati Prajna. Per from Tibet., Foreword., Footnote, decree. D.B. Dashiev. Moscow: Vost. Lit. 2008. 214p. (russian)

[9] D.N. Olennikov, N.I. Kashchenko, N.K. Chirikova, A Novel HPLC-Assisted Method for Investigation of the Fe2+-Chelating Activity of Flavonoids and Plant Extracts. Molecules. 2014. Vol.19. P.18296-18316.

[10] D.N. Olennikov, N.I. Kashchenko, N.K. Chirikova, S.S. Kuz'mina. Phenolic Profile of Potentilla anserina L. (Rosaceae) Herb of Siberian Origin and Development of a Rapid Method for Simultaneous Determination of Major Phenolics in P. anserina Pharmaceutical Products by Microcolumn RP-HPLCUV - 2015. Molecules. Vol.20. P.224-248. 